\title{
Altered follicular helper T cell impaired antibody production in a murine model of myelodysplastic syndromes
}

\author{
Huijuan Jiang ${ }^{1, *}$, Ningbo Cui ${ }^{1, *}$, Liyan Yang $^{1, *}$, Chunyan Liu ${ }^{1}$, Lanzhu Yue ${ }^{1}$, Lifang \\ Guo ${ }^{1}$, Huaquan Wang ${ }^{1}$ and Zonghong Shao ${ }^{1}$ \\ ${ }^{1}$ Department of Hematology, General Hospital, Tianjin Medical University, Tianjin 300052, China \\ *These authors contributed equally to this work \\ Correspondence to: Huaquan Wang, email: wanghuaquan@tmu.edu.cn
}

Keywords: myelodysplastic syndromes, follicular helper T cell, CXCR5, PD-1, ICOS

Received: February 06, 2017 Accepted: September 21, $2017 \quad$ Published: October 06, 2017

Copyright: Jiang et al. This is an open-access article distributed under the terms of the Creative Commons Attribution License 3.0 (CC BY 3.0), which permits unrestricted use, distribution, and reproduction in any medium, provided the original author and source are credited.

\section{ABSTRACT}

Myelodysplastic syndromes (MDS) are a group of clonal hematopoietic diseases which have a high risk of progressing to acute myeloid leukemia. MDS patients have immunologic deficiency, including $T$ and $B$ cells dysfunction. Follicular $T$ helper cells ( $\mathrm{Tfh}, \mathrm{CD}^{+}{ }^{+} \mathrm{CXCR5}^{+}$) are an important subset of helper $\mathrm{T}$ cells which help to the formation of germinal centers and B cells differentiation. In this study, we investigated the proportion and function of Tfh using NUP98-HOXD13 transgenic (NHD13) mice model with MDS phenotype. The proportion of Tfh from bone marrow and spleen of NHD13 mice decreased compared with wild type (WT) mice tested by flow cytometry. In NHD13 mice spleens, there were decreased CXCR5 ${ }^{+}$cells and increased PD-1 ${ }^{+}$cells using immunohistochemistry. The active markers (ICOS, CD40L and OX40) expressed on Tfh of NHD13 mice were decreased. In contrast, PD-1 expression on Tfh of NHD13 mice was higher than that of WT mice. After coculture with Tfh from NHD13 mice, IgG and IgM production of B cells were decreased. In conclusion, the proportion and function of Tfh in the MDS mice model were altered. The dysfunction and reduction of Tfh may inhibit B cells differentiation and antibody production. Abnormal Tfh might contribute to the immune tolerance promoting the progression of MDS.

\section{INTRODUCTION}

Myelodysplastic syndromes (MDS) are a group of heterogeneous malignant clonal diseases of hematopoietic stem cells (HSC), characterized by a normal or hypercellular bone marrow with ineffective and dysplastic hematopoiesis resulting in cytopenia. MDS usually have high mortality, poor prognosis and a lack of specific treatments. Many studies have confirmed that MDS have a high risk of transformation to acute leukemia (AML) due to increased malignant hematopoietic clones (leukemic stem cells, LSC) [1-4].

The pathogenesis of MDS is still unclear. Until now, researchers have demonstrated that altered cytogenetics (including somatic gene mutation, epigenesis, haploinsufficiency) and micro-environments contribute to the pathogenesis and progression of MDS. Abnormal DNA methylation, RNA splicing, or chromatin modification (such as DNMT3A, TET2, SF3B1, EZH2, ASXL1, et al.) participate in the mechanisms of MDS. The gene mutation or molecular abnormalities of HSC induce transformation to LSC $[5,6]$. Recently, some studies have proved that abnormal immune systems facilitate the development of MDS and the progression to AML [7-9]. Immune deficiency may lead to immune escape of LSC resulting in malignant clone proliferation [10].

The NUP98-HOXD13 (NHD13) fusion gene, which is constructed with nucleoporin 98KDa (NUP98) amino terminus and human homeobox 13 (HOXD13) fusion gene, occurs in MDS or acute nonlymphocytic leukemia patients. In 2005, Lin YW et al. reported a NHD13 transgenic mouse model for MDS, by mouse vav1 oncogene expression regulatory elements in C57BL/6J WT mice [11]. The transgene was expressed specifically 
in hematopoietic tissues, including thymus, spleen and bone marrow. NHD13 mice can develop MDS phenotype at an early age, and more than half of these mice progress to AML between 4 and 14 months of age. Thus, NHD13 mice are the most commonly used as MDS mouse models [12-16]. In previous studies, NHD13 mice showed altered hematopoietic stem /progenitor cells (HSPCs), abnormal bone marrow microenvironment (BMME) and immune dysfunction including dysfunctional B cells [17, 18].

Follicular helper $\mathrm{T}$ cells ( $\mathrm{Tfh}$ ) are new subsets of CD4+ T lymphocytes, which can induce the proliferation and differentiation of B cells. IL-21, the major cytokine produced by Tfh, can promote B cells to differentiate into plasma cells and induce antibodies production by interacting with its receptors on $\mathrm{B}$ cells. The major chemokine receptor of Tfh is CXCR5 [19, 20].

In this study, we investigated the proportion and function of Tfh in NHD13 mice to explore the role of Tfh in B cell dysfunction in MDS. We found that the proportion and function of Tfh were aberrant in MDS mice models which could impair antibody production of B cells.

\section{RESULTS}

\section{The proportion of $\mathrm{Tfh}$ from $\mathrm{BM}$ and spleen of NHD13 mice were decreased}

The proportion of $\mathrm{Tfh}(\mathrm{CD} 4+\mathrm{CXCR} 5+)$ from $\mathrm{BM}$ of NHD13 mice $(2.20 \pm 0.54 \%)$ was lower than that of WT mice $(5.15 \pm 0.68 \%, P<0.01)$ (Figure $1 \mathrm{~A})$. The proportion of Tfh from spleen of NHD13 mice $(0.38 \pm 0.04 \%)$ was lower than that of WT mice $(0.66 \pm 0.17 \%)$. But there was no statistical difference $(P>0.05)$. (Figure 1B).

\section{The PD-1 expression on Tfh from BM and spleen of NHD13 mice were increased}

The PD-1 expression on Tfh from BM of NHD13 mice $(33.82 \pm 0.91 \%)$ was higher than that of WT mice $(23.51 \pm 2.86 \%, P<0.01)$ (Figure 2A). The PD-1 expression on Tfh from spleen of NHD13 mice $(28.09 \pm$ $1.86 \%)$ was higher than that of WT mice $(13.35 \pm 1.60 \%$, $P<0.01$ ) (Figure 2B). The expression of PD-1 mRNA of Tfh from spleen from NHD13 mice was (16.35 \pm 3.17$)$, which was higher than that of WT mice $(1.28 \pm 0.53 \%$, $P<0.01$ ) (Figure 2C).

\section{The OX40, ICOS and CD40L expression on Tfh of NHD13 mice were decreased, especially in spleen}

The OX40 expression on Tfh from BM of NHD13 mice $(23.15 \pm 1.35 \%)$ was lower than that of WT mice $(30.16 \pm 2.45 \%, P<0.05)$. The ICOS expression on Tfh from BM of NHD13 mice was $(33.42 \pm 1.06) \%$, while that of WT mice was $(33.16 \pm 3.98) \%$. The CD40L expression on Tfh from BM of NHD13 mice was $(22.94 \pm 1.10) \%$, while that of WT mice was $(23.45 \pm 1.34) \%$. There were no statistical differences in ICOS or CD40L expression between the two groups (both $P>0.05$ ) (Figure 3A).

The expression of OX40 $(10.46 \pm 1.87 \%)$, ICOS $(16.46 \pm 1.78 \%)$ and CD40L $(17.88 \pm 2.17 \%)$ on $\mathrm{Tfh}$ from spleen of NHD13 mice was lower than those of WT mice $(18.36 \pm 2.45 \%, 25.43 \pm 2.68 \%, 28.63 \pm 2.12 \%$, respectively) (all $P<0.05$ ) (Figure $3 \mathrm{~B}$ ).

\section{CXCR5 expression was lower and PD-1 expression was higher on spleen cells using IHC}

Spleen lymphoid follicles and germinal centers of NHD13 mice were significantly reduced. Red pulps of NHD13 mice spleen were widened (Figure 4A). IHC results showed that NHD13 mice had lower CXCR5 (Figure 4B) expression and higher PD-1 expression on spleen cells compared with WT mice (Figure 4C).

\section{Serum IgG and IgM levels of NHD13 mice were decreased}

The serum levels of $\operatorname{IgG}(88.27 \pm 13.03 \mathrm{mg} / \mathrm{dL})$ and $\operatorname{IgM}(21.88 \pm 1.18 \mathrm{mg} / \mathrm{dL})$ of NHD13 mice were decreased compared with those of WT mice (213.30 \pm $7.95 \mathrm{mg} / \mathrm{dL}$ and $47.39 \pm 3.28 \mathrm{mg} / \mathrm{dL}$, respectively, both $P<0.01$ ) (Figure 5A).

\section{The IgG and IgM production of B cells were decreased after co-culture with Tfh $_{\text {NHD13 }}$}

After co-cultured with auto-Tfh $\left(\mathrm{Tfh}_{\mathrm{WT}}\right)$, the $\mathrm{IgG}$ and IgM production of B cells from WT mice (B cell ${ }_{\mathrm{WT}}$ ) were $(411.3 \pm 35.69) \mathrm{ng} / \mathrm{ml}$ and $(91.33 \pm 8.37) \mathrm{ng} / \mathrm{ml}$, respectively $(N=3)$. After co-culture with auto-Tfh $\left(\mathrm{Tfh}_{\mathrm{NHD13}}\right)$, the IgG and IgM production of B cells from NHD13 mice (B cell $\left.{ }_{\mathrm{NHD} 13}\right)$ were $(52.67 \pm 7.54) \mathrm{ng} / \mathrm{ml}$ and $(24.67 \pm 3.84) \mathrm{ng} / \mathrm{ml}$, respectively $(N=3)$. After $\mathrm{Tfh}_{\mathrm{NHD} 13}$ $+\mathrm{B}$ cell $_{\mathrm{wT}}$ co-culture, the $\mathrm{IgG}$ and $\mathrm{IgM}$ production of $\mathrm{B}$ cell $_{\mathrm{WT}}$ were $(137.0 \pm 19.50) \mathrm{ng} / \mathrm{ml}$ and $(60.00 \pm 2.65)$ $\mathrm{ng} / \mathrm{ml}$, respectively $(N=3)$. After $\mathrm{Tfh}_{\mathrm{wT}}+\mathrm{B}$ cell $_{\mathrm{NHD} 13}$ co-culture, the $\operatorname{IgG}$ and $\mathrm{IgM}$ production of $\mathrm{B}$ cell ${ }_{\mathrm{NHD13}}$ were $(156.3 \pm 15.62) \mathrm{ng} / \mathrm{ml}$ and $(54.00 \pm 4.04) \mathrm{ng} / \mathrm{ml}$, respectively $(N=3)$. These results indicated that the $\mathrm{IgG}$ and IgM production of B cells was decreased after coculture with Tfh ${ }_{\mathrm{NHD} 13}$. Furthermore, both Tfh and B cells function were impaired in NHD13 mice (Figure 5B).

\section{DISCUSSION}

MDS are a group of clonal hematopoietic diseases with a high risk of transforming into AML. Recent studies have confirmed that immunological abnormalities play important roles in MDS pathogenesis [1]. Previous studies showed that patients with MDS had aberrant cellular and 
A
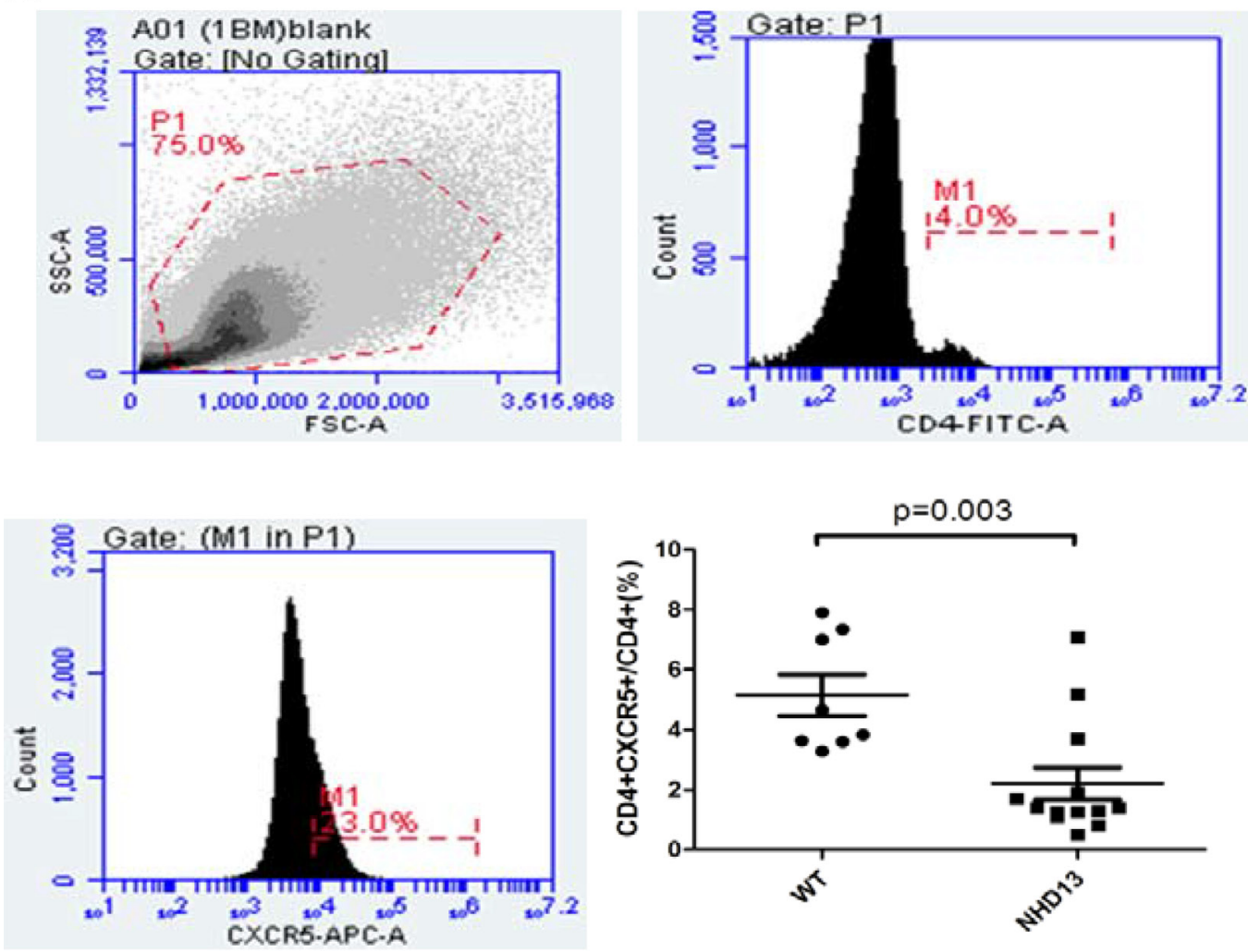

B
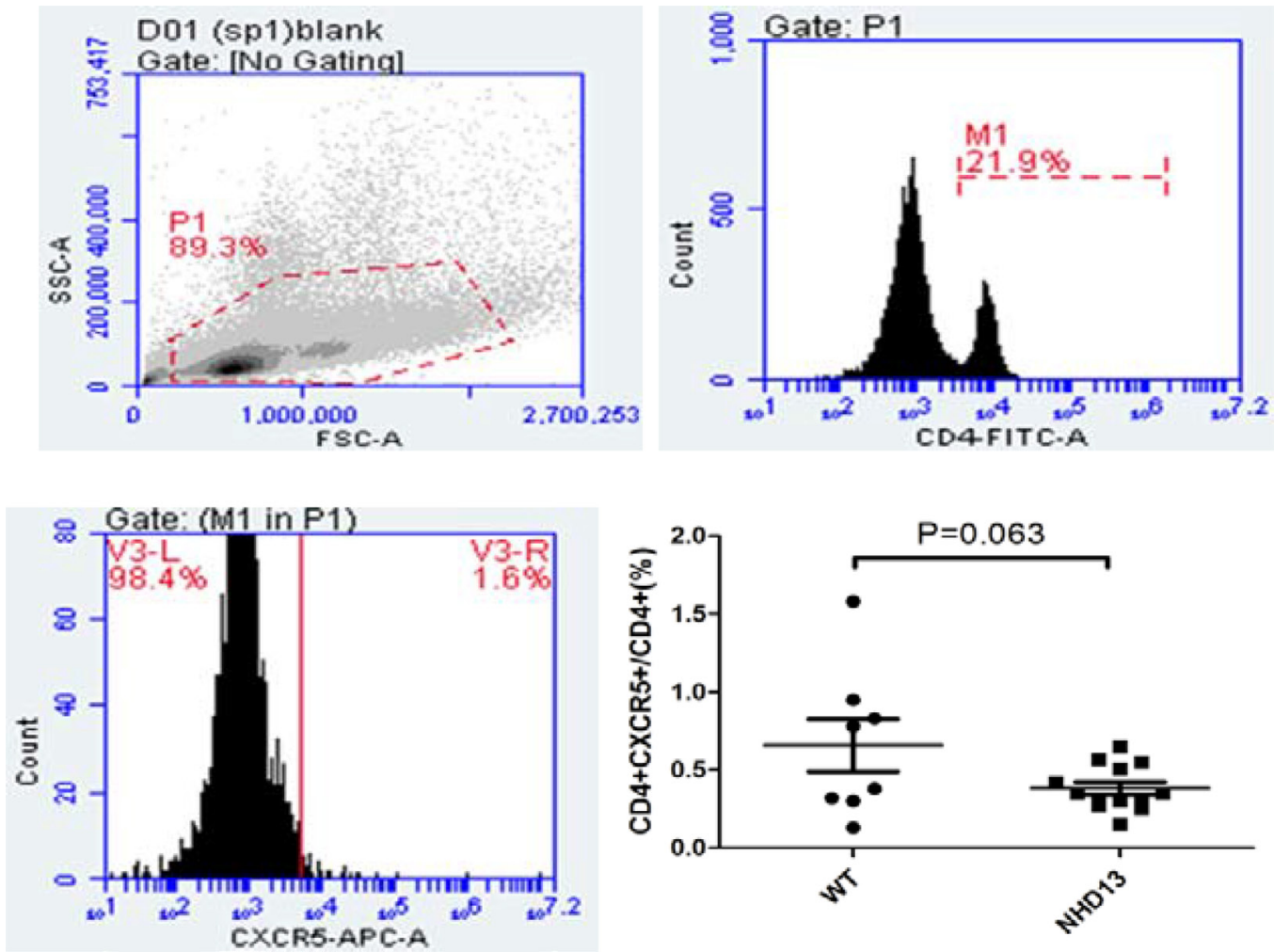

Figure 1: (A) The proportion of Tfh in BM of NHD13 mice was lower than that of WT mice $(P<0.01)$. (B) The proportion of Tfh in spleen of NHD13 mice was lower than that of WT mice, but the difference had no statistical significance $(P>0.05)$. 
humoral immunity, including defective T cells and B cells, decreased helper $\mathrm{T}$ cells $(\mathrm{Th})$ and increased regulatory $\mathrm{T}$ cells (Treg). MDS patients with immune dysfunction cannot clean up malignant clones [7, 9, 21]. Hence, altered immune status in MDS may accelerate LSC survival and amplification, which help to AML transformation.

In NHD13 mouse model, Balderman SR et al. [18] proved that altered bone marrow microenvironments (BMME) may facilitate the progression of MDS. There was accelerated AML transformation and mortality rate in NHD13 compared with WT. And replacement of the MDS BMME with a WT BMME in mice model showed mitigated transformation to leukemia and death in recipients of NHD13 marrow. Though immune cells as the important components of BMME, Choi CW et al. [22] reported that NHD13 mice had lymphopenia with decreased T and B lymphocytes counts. NHD13 mice also had abnormal differentiation from pro-B to pre-B cells. This suggested that impaired differentiation and function in B lymphocytes might promote the development of MDS.

Tfh is the main subset of Th which assistant with differentiation and antibodies production of B cells. We found that NHD13 mice at 6-8 weeks had cytopenia
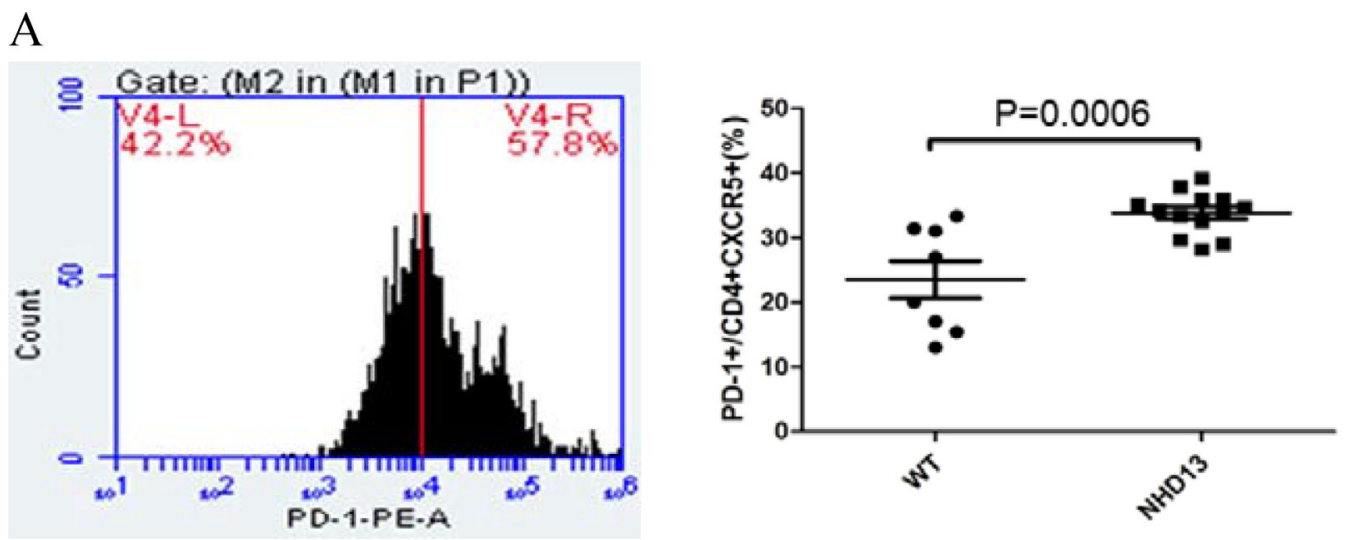

B
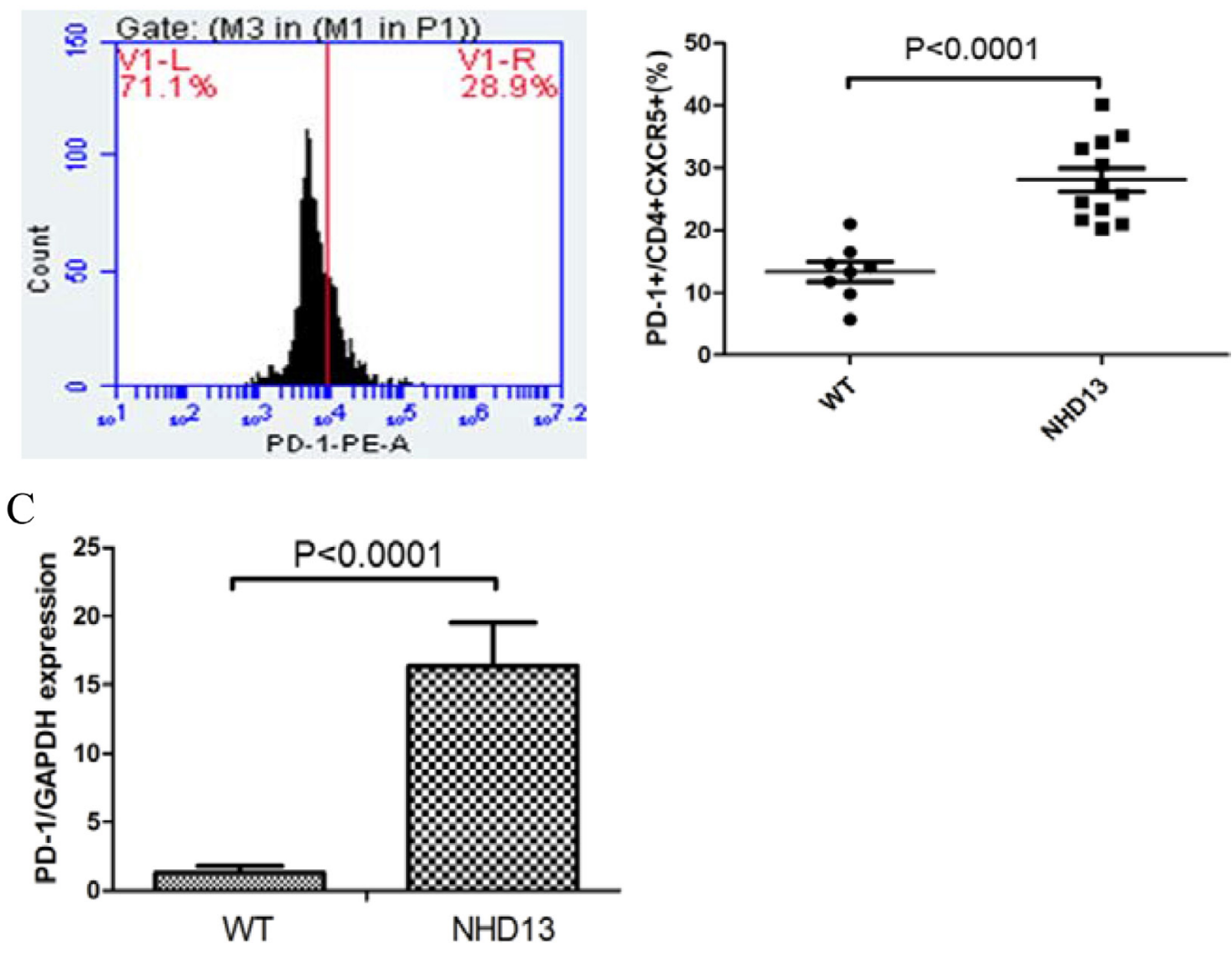

Figure 2: (A) PD-1 expression on Tfh from BM of NHD13 mice was higher than that of WT mice $(P<0.01)$. (B) PD-1 expression on Tfh from spleen of NHD13 mice was higher than that of WT mice $(P<0.01)$. (C) PD-1 mRNA expression in Tfh from spleen of NHD13 mice was higher than that of WT mice $(P<0.01)$. 
and dysplasia as morphological changes of MDS (Supplementary Figures 2-3). Compared with WT mice, the proportions of Tfh in BM and spleen from NHD13 mice were decreased, especially in BM. The active markers (including ICOS, CD40L and OX40) expressed on Tfh of NHD13 mice were decreased. Meanwhile, NHD13 mice had lower serum IgG and IgM levels compared with WT mice. After co-culture with Tfh from NHD13 mice, $\mathrm{IgG}$ and $\mathrm{IgM}$ production of $\mathrm{B}$ cells was decreased. These results indicated that reduction and dysfunction in Tfh could impair B cells function and humoral immunity in MDS mouse model.
In this study, we measured PD-1 expression on Tfh from NHD13 mice compared with WT mice. We found PD-1 expression on Tfh was significantly increased in NHD13 mice. Thus, we inferred that the reduction of Tfh in MDS might be due to increased PD-1 expression on Tfh.

PD-1 is an immunosuppressive receptor which is expressed on activated T lymphocytes, B lymphocytes and macrophages. PD-L1 is the major ligand of PD-1 expressed on non-lymphoid tissues and activated antigen presenting cells (APC) $[23,24]$. PD-1 plays an important role in the establishment of immune tolerance and prevention of autoimmune diseases [25]. In normal
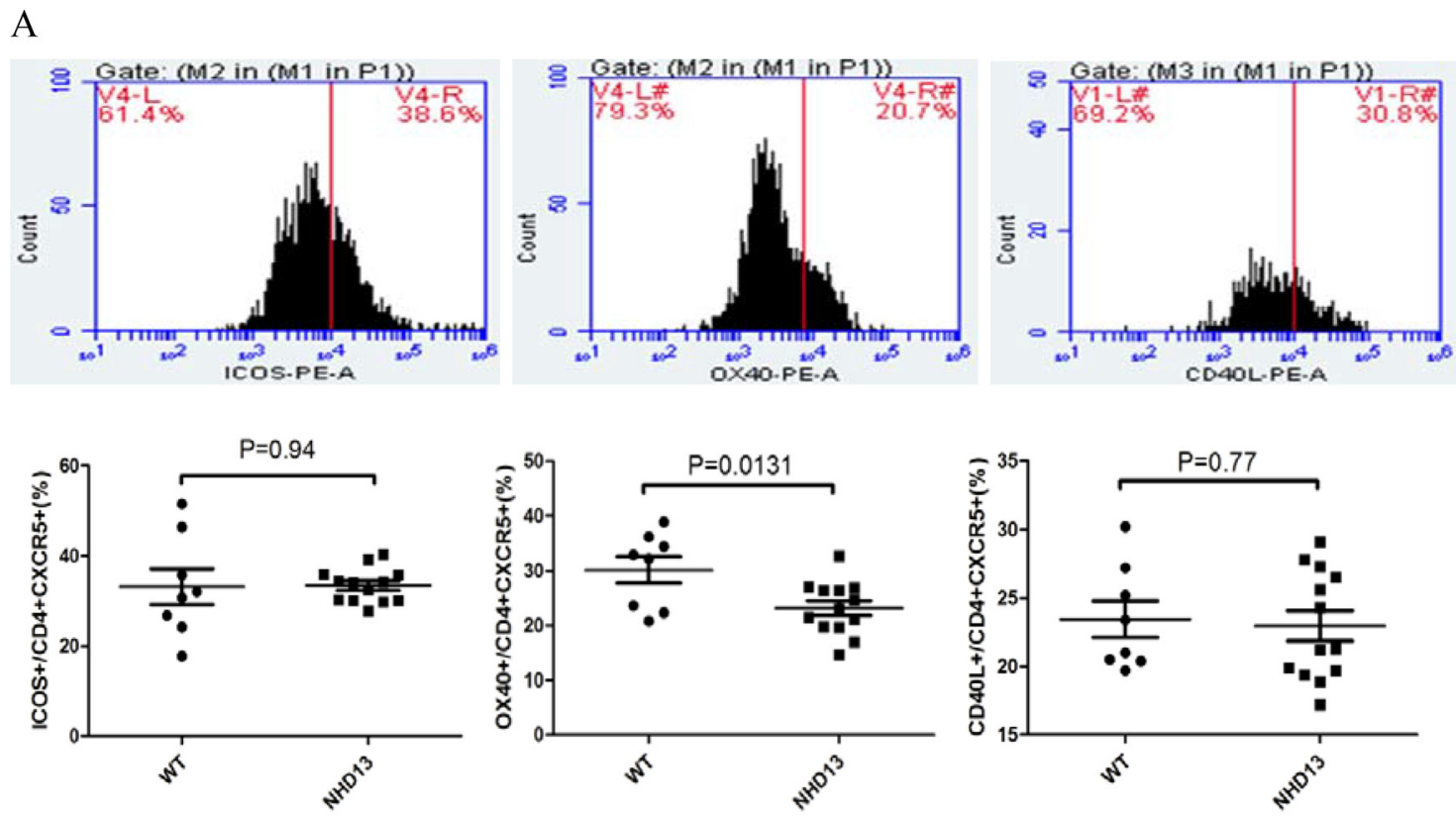

B
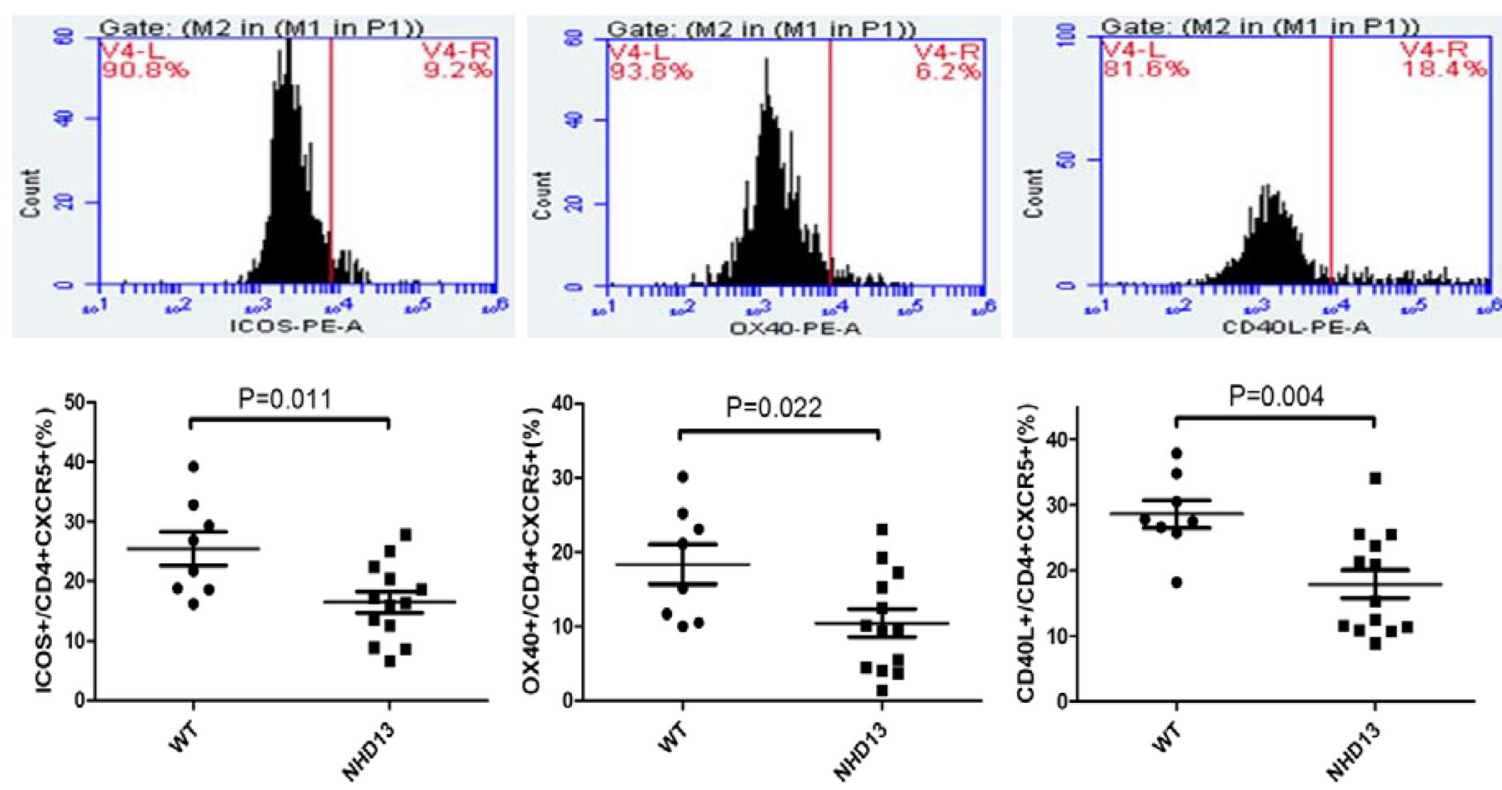

Figure 3: (A) The OX40 expression on Tfh from BM of NHD13 mice was lower than that of WT mice $(P<0.05)$. There were no statistical differences in ICOS or CD40L expression between two groups (both $P>0.05$ ). (B) The expression of OX40, ICOS and CD40L on Tfh from spleen of NHD13 mice were lower than those of WT mice (all $P<0.05$ ). 
conditions, PD-1 could maintain immune tolerance to self-antigens interacting with PD-L1. A combination of PD-1 and PD-L1 contribute to negative regulation in the immune network, which inhibit the proliferation and activation of lymphocyte or the release of inflammatory cytokines $[9,26]$.

In recent years, researchers have confirmed that $\mathrm{PD}$ L1 was highly expressed on many kinds of tumors cells. PD-L1 interacting with PD-1 on lymphocytes infiltrated in tumor tissues could inhibit anti-tumor response of lymphocytes, leading to immune escape of tumor cells $[8,27]$. PD-L1 and/or PD-1 blockades have achieved clinical benefits in cancer treatments. In a clinical trial of advanced tumor cases (including 207 various types), the response rate of PD-L1 blockade treatment was 6-17\% [28]. In another clinical trial of BMS-936558 (296 cases of various types of cancer patients), the response rate of advanced non-small cell lung cancer was $18 \%, 28 \%$ of melanoma, and $27 \%$ of renal cell carcinoma [29]. In an international multi-center clinical trial of drug-resistant
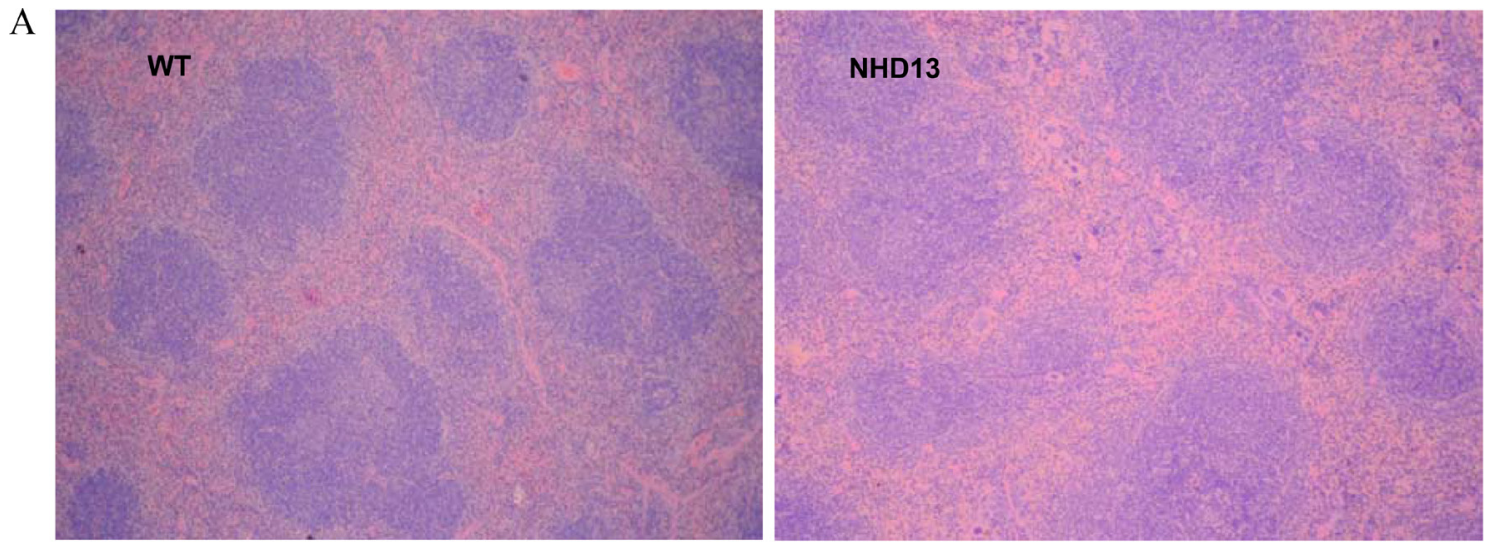

B
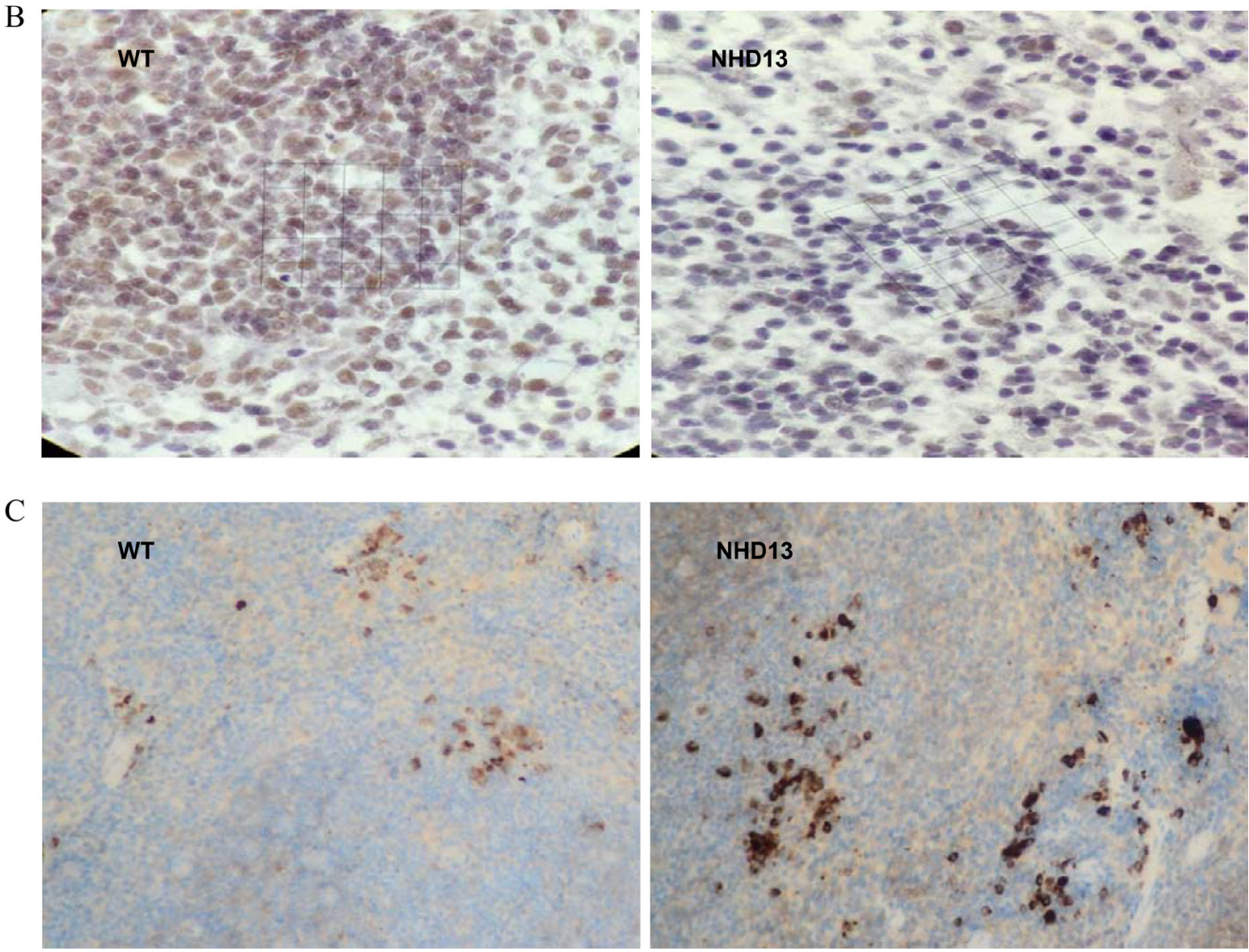

Figure 4: CXCR5 and PD-1 expression were tested by IHC. (A) In NHD13 mice, the spleen lymphoid follicles and germinal centers were reduced, and red pulps were widened $(10 \times 10$ visual field), (B) CXCR5 expression on spleen cells from NHD13 mice was lower than that of WT mice $(10 \times 40$ visual field $),($ C) PD-1 expression on spleen cells from NHD13 mice was higher than that of WT mice $(10 \times 10$ visual field $)$. 
refractory melanoma, PD-1 blockade pembrolizumab induced a $26 \%$ response rate with mild side effects [30].

In malignant hematological diseases, the clinical trials of PD-1 blockade (nivolumab) in treatments of refractory and relapsed Hodgkin lymphoma showed that $87 \%$ of patients had good response, including $17 \%$ with a complete response (CR) rate [31]. Yang $\mathrm{H}$ et al. [32] also suggested that PD-1 signaling was involved in MDS pathogenesis and resistance mechanisms to hypomethylating treatments. According to our results, we inferred that increased PD-1 on Tfh might contribute to the reduction and dysfunction of Tfh in MDS. The blockade of the PD-1 pathway might be of benefit to MDS patients.

We also measured the proportion of Tfh and PD-1 expression on Tfh from MDS patient samples. The data showed similar tendency to the results of mice model (Supplementary Table 1, Supplementary Figure 4). But sample size was very limited which need further studies.
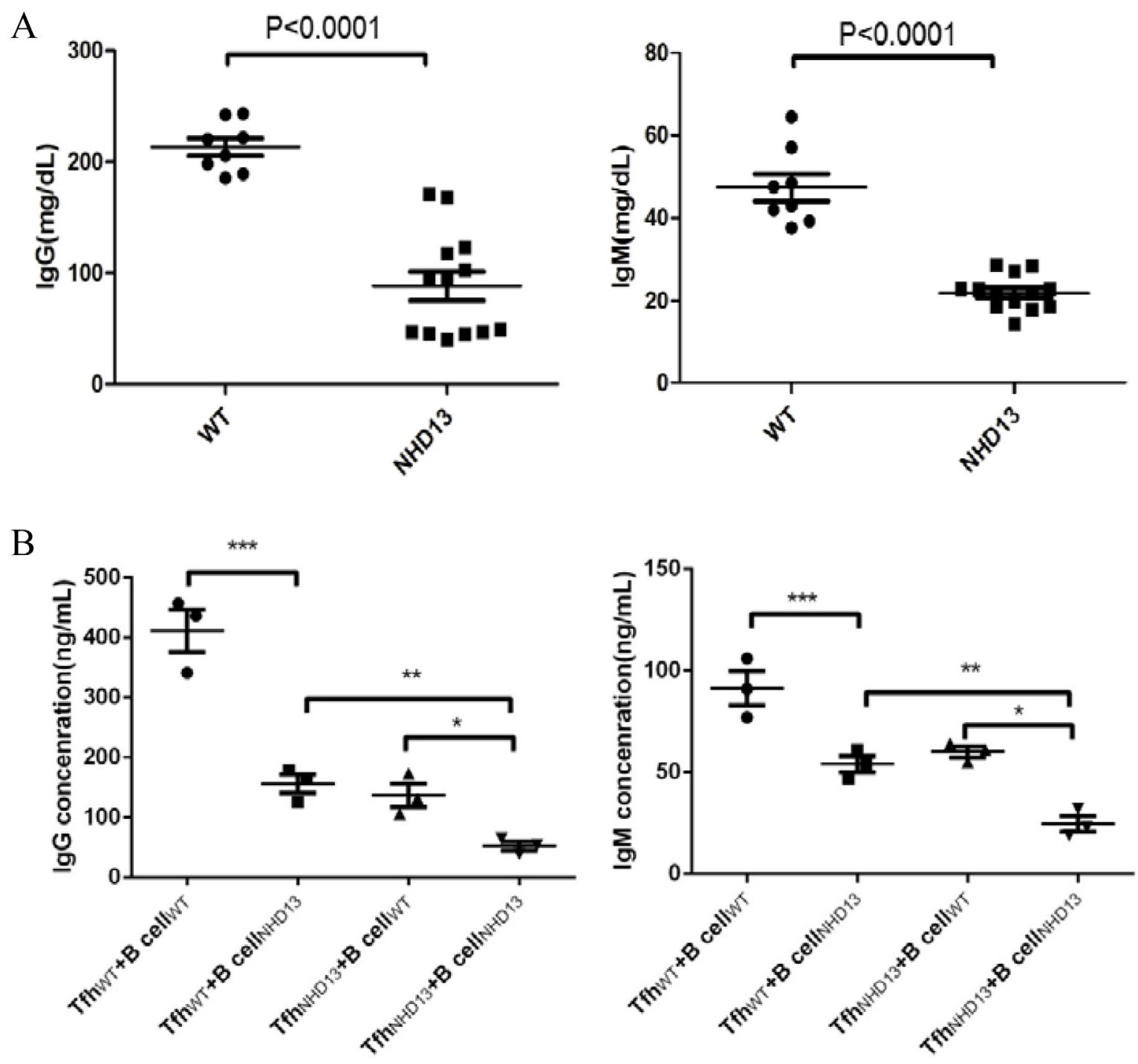

Figure 5: (A) The serum IgG and IgM levels of NHD13 mice were decreased compared with that of WT mice (both $P<0.01$ ). (B) Compared with $\mathrm{Tfh}_{\mathrm{wT}}+\mathrm{B}$ cell ${ }_{\mathrm{wT}}$ co-culture, the IgG and IgM production of B cells were decreased after co-cultured with Tfh $\mathrm{NHD}_{13}$. Meanwhile, the $\operatorname{IgG}$ and $\operatorname{IgM}$ production were lowest in co-culture of $\left.\mathrm{Tfh}_{\mathrm{NHD} 13}+\mathrm{B} \operatorname{cell}_{\mathrm{NHD} 13} \cdot{ }^{* * * * * * *} P<0.05\right)$. 
Center of the Institute of Radiation Medicine, Academy of Medical Science and Peking Union Medical College. All studies were approved by the Tianjin Medical University intramural animal care and use committee.

\section{The detection of the quantity and programmed death 1 receptor (PD-1) expression on Tfh from mice spleen and bone marrow by flow cytometry (FCM)}

The spleen samples were obtained from NHD13 and WT mice, and were stored in $2 \mathrm{ml}$ PBS and gently ground. The cell suspension was acquired after being filtered, centrifuged and after hemolysis (Hemolysin, Becton Dickinson Company, USA). Finally, $1 \times 10^{6}$ cells were immunostained with rat-anti-mouse monoclonal CD4FITC, CXCR5-APC, PD-1-PE, OX40-PE, ICOS-PE and CD40L-PE (BD company, USA) respectively, and analyzed by FCM (BD Accuri C6, BD company, USA). Meanwhile, $\mathrm{BM}$ samples were acquired from the femur of the mice. After being filtered, $1 \times 10^{6}$ cells were stained with CD4-FITC, CXCR5-APC, PD-1-PE, OX40-PE, ICOS-PE and CD40L$\mathrm{PE}$ respectively, and analyzed by FCM. The data was analyzed by BD Accuri C6 software (BD Company, USA).

\section{Immunohistochemistry (IHC)}

The 4-6 $\mu \mathrm{m}$ sections of paraffin embedded tissues were stained with CXCR5 antibody (abcam, USA) or PD-1 antibody (abcam, USA). Deparaffinized tissue sections were pretreated with $3.0 \%$ hydrogen peroxide in methanol for at least 15 minutes to block endogenous peroxidase activity. The tissue sections were incubated with the primary antibodies diluted in $1 \%$ animal serum PBS-T at room temperature for between and 1 and 2 hours. Subsequently, the tissue sections were incubated with secondary antibody at room temperature for 1 hour following the manufacturer's guidelines for reagent preparation.

\section{The expression of PD-1 mRNA of sorted Tfh cells from spleen}

Tfh (CD4+CXCR5+ cells) from spleen of NHD13 and WT mice were sorted by the FACSAria (BD Biosciences). Total RNA was extracted using Trizol (Takara Bio, CA), and cDNA was generated using reverse transcriptase kit (Takara Bio,CA). Acquired the same amount of cDNA, performed $\mathrm{qPCR}$ reaction. The reaction system was $25 \mathrm{uL}$ : $\mathrm{SYBR}^{\circledR}$ Premix Ex Taq II (Takara Bio, China) 12.5ul, forward and reverse primer, each $0.5 \mathrm{ul}$, and sterilized distilled water and samples total 11.5ul. Primers used are listed as follows: PD-1 forward 5'- TTGACAGCAGGGAAGGAAAG -3' reverse 5'AGGAGAGCCAGAACCCAACT -3'; GAPDH forward
5'- ACGGCAAATTCAACGGCACAGTCA -3', reverse 5'- TGGGGGCATCGGCAGAAGG -3'. Applied Bio-Rad CFX Manager software, each group relative quantitative using 2- $\Delta \Delta \mathrm{Ct}$ values: $\Delta \Delta \mathrm{Ct}=\left(\mathrm{C}_{\text {ttarget }}-\mathrm{C}_{\mathrm{tGAPDH}}\right)$ target $\left(\mathrm{C}_{\text {ttarget }}-\mathrm{C}_{\mathrm{tGAPDH}}\right) \mathrm{ctrl}$.

\section{Serum and IgG and IgM detected by ELISA}

The levels of serum IgG and IgM were measured by ELISA kit according to the manufacturer's instructions (Bethyl Laboratories).

\section{Tfh and B cells co-culture}

Tfh were sorted by the FACSAria (BD Biosciences) (from spleen). B cells (from spleen) were sorted by the MACS kit (Miltenyi Biotec). Sorted cell purity was $>90 \%$ (Supplementary Figure 1). Tfh and B cells (25 000 cells per well, 1:1 ratio) were co-cultured in RPMI 1640 medium (containing L-glutamine, penicillin, streptomycin, $10 \%$ fetal bovine serum, and $1 \mathrm{mg} / \mathrm{mL}$ staphylococcal enterotoxin (SEB; Toxin Technology)) for 7 days. IgG and IgM were measured by ELISA kit (Bethyl Laboratories).

\section{Statistical analysis}

All statistical analyses were performed with SPSS 20.0 software (SPSS Science). The data is presented as mean \pm SEM. For normal distribution data between two independent groups, Student's $t$-test was used. For skewed distribution data, Wilcoxon test was used. A value of $P<0.05$ was considered to be statistically significant.

\section{ACKNOWLEDGMENTS}

Contributions: H.J. and N.C. performed research and analyzed the data; H.W. designed the research, ensured correct analysis of the data, and wrote the manuscript; L.Y., C.L., L.Y., L.G., and Z.S. assisted in the design of the research, oversaw the collection of the data, and contributed to the writing of the manuscript. All authors critically revised the manuscript and gave final approval of the manuscript.

\section{CONFLICTS OF INTEREST}

The author declares no conflicts of interest.

\section{FUNDING}

This project is partly supported by The National Natural Science Foundation of China (No. 81170472, 81400088, 81570111, 81500101), Application Bases and Advanced Technology Research Program of Tianjin (No. 14JCYBJC27200, 09JCYBJC11200). 


\section{REFERENCES}

1. Tefferi A, Vardiman JW. Myelodysplastic syndromes. N Engl J Med. 2009; 361:1872-1885.

2. Bejar R, Steensma DP. Recent developments in myelodysplastic syndromes. Blood. 2014; 124:2793-2803.

3. Ades L, Itzykson R, Fenaux P. Myelodysplastic syndromes. Lancet. 2014; 383:2239-2252.

4. Tehranchi R, Woll PS, Anderson K, Buza-Vidas N, Mizukami T, Mead AJ, Astrand-Grundstrom I, Strombeck B, Horvat A, Ferry H, Dhanda RS, Hast R, Ryden T, et al. Persistent malignant stem cells in $\operatorname{del}(5 \mathrm{q})$ myelodysplasia in remission. N Engl J Med. 2010; 363:1025-1037.

5. Papaemmanuil E, Gerstung M, Malcovati L, Tauro S, Gundem G, Van Loo P, Yoon CJ, Ellis P, Wedge DC, Pellagatti A, Shlien A, Groves MJ, Forbes SA, et al, and Chronic Myeloid Disorders Working Group of the International Cancer Genome Consortium. Clinical and biological implications of driver mutations in myelodysplastic syndromes. Blood. 2013; 122:3616-27.

6. Goardon N, Nikolousis E, Sternberg A, Chu WK, Craddock C, Richardson P, Benson R, Drayson M, Standen G, Vyas P, Freeman S. Reduced CD38 expression on CD34+ cells as a diagnostic test in myelodysplastic syndromes. Haematologica. 2009; 94:1160-1163.

7. Olnes MJ, Sloand EM. Targeting immune dysregulation in myelodysplastic syndromes. JAMA. 2011; 305:814-819.

8. Mekinian A, Grignano E, Braun T, Decaux O, Liozon E, Costedoat-Chalumeau N, Kahn JE, Hamidou M, Park S, Puechal X, Toussirot E, Falgarone G, Launay D, et al. Systemic inflammatory and autoimmune manifestations associated with myelodysplastic syndromes and chronic myelomonocytic leukaemia: a French multicentre retrospective study. Rheumatology (Oxford). 2016; 55:291-300.

9. Kordasti SY, Ingram W, Hayden J, Darling D, Barber L, Afzali B, Lombardi G, Wlodarski MW, Maciejewski JP, Farzaneh F, Mufti GJ. CD4+CD25high Foxp3+ regulatory T cells in myelodysplastic syndrome (MDS). Blood. 2007; 110:847-850.

10. Aggarwal $\mathrm{S}$, van de Loosdrecht AA, Alhan C, Ossenkoppele GJ, Westers TM, Bontkes HJ. Role of immune responses in the pathogenesis of low-risk MDS and high-risk MDS: implications for immunotherapy. Br J Haematol. 2011; 153:568-581.

11. Lin YW, Slape C, Zhang Z, Aplan PD. NUP98-HOXD13 transgenic mice develop a highly penetrant, severe myelodysplastic syndrome that progresses to acute leukemia. Blood. 2005; 106:287-295.

12. Slape C, Liu LY, Beachy S, Aplan PD. Leukemic transformation in mice expressing a NUP98-HOXD13 transgene is accompanied by spontaneous mutations in Nras, Kras, and Cbl. Blood. 2008; 112:2017-2019.

13. Choi CW, Chung YJ, Slape C, Aplan PD. Impaired differentiation and apoptosis of hematopoietic precursors in a mouse model of myelodysplastic syndrome. Haematologica. 2008; 93:1394-1397.

14. Xu H, Menendez S, Schlegelberger B, Bae N, Aplan PD, Gohring G, Deblasio TR, Nimer SD. Loss of p53 accelerates the complications of myelodysplastic syndrome in a NUP98-HOXD13-driven mouse model. Blood. 2012; 120:3089-3097.

15. Guirguis AA, Slape CI, Failla LM, Saw J, Tremblay CS, Powell DR, Rossello F, Wei A, Strasser A, Curtis DJ. PUMA promotes apoptosis of hematopoietic progenitors driving leukemic progression in a mouse model of myelodysplasia. Cell Death Differ. 2016; 23:1049-1059.

16. Cheng G, Liu F, Asai T, Lai F, Man N, Xu H, Chen S, Greenblatt S, Hamard PJ, Ando K, Chen X, Wang L, Martinez C, et al. Loss of p300 accelerates MDS-associated leukemogenesis. Leukemia. 2017; 31:1382-1390.

17. Puthiyaveetil AG, Heid B, Reilly CM, HogenEsch H, Caudell DL. A NUP98-HOXD13 leukemic fusion gene leads to impaired class switch recombination and antibody production. Exp Hematol. 2012; 40:622-633.

18. Balderman SR, Li AJ, Hoffman CM, Frisch BJ, Goodman AN, LaMere MW, Georger MA, Evans AG, Liesveld JL, Becker MW, Calvi LM. Targeting of the bone marrow microenvironment improves outcome in a murine model of myelodysplastic syndrome. Blood. 2016; 127:616-625.

19. Ueno H, Banchereau J, Vinuesa CG. Pathophysiology of T follicular helper cells in humans and mice. Nat Immunol. 2015; 16:142-152.

20. Crotty S. T follicular helper cell differentiation, function, and roles in disease. Immunity. 2014; 41:529-542.

21. Ganan-Gomez I, Wei Y, Starczynowski DT, Colla S, Yang H, Cabrero-Calvo M, Bohannan ZS, Verma A, Steidl U, Garcia-Manero G. Deregulation of innate immune and inflammatory signaling in myelodysplastic syndromes. Leukemia. 2015; 29:1458-1469.

22. Choi CW, Chung YJ, Slape C, Aplan PD. A NUP98HOXD13 fusion gene impairs differentiation of $\mathrm{B}, \mathrm{T}$ lymphocytes and leads to expansion of thymocytes with partial TCRB gene rearrangement. J Immunol. 2009; 183:6227-35.

23. Hutchinson L. Haematological cancer: PD-1 blockade: opening the door to attack. Nat Rev Clin Oncol. 2015; 12:65.

24. Barber DL, Wherry EJ, Masopust D, Zhu B, Allison JP, Sharpe AH, Freeman GJ, Ahmed R. Restoring function in exhausted CD8 $\mathrm{T}$ cells during chronic viral infection. Nature. 2006; 439:682-687.

25. Iwai Y, Ishida M, Tanaka Y, Okazaki T, Honjo T, Minato N. Involvement of PD-L1 on tumor cells in the escape from host immune system and tumor immunotherapy by PD-L1 blockade. Proc Natl Acad Sci USA. 2002; 99:12293-12297.

26. Dulos J, Carven GJ, van Boxtel SJ, Evers S, DriessenEngels LJ, Hobo W, Gorecka MA, de Haan AF, Mulders P, 
Punt CJ, Jacobs JF, Schalken JA, Oosterwijk E, et al. PD-1 blockade augments Th1 and Th17 and suppresses Th2 responses in peripheral blood from patients with prostate and advanced melanoma cancer. J Immunother. 2012; 35:169-178.

27. Dong H, Strome SE, Salomao DR, Tamura H, Hirano F, Flies DB, Roche PC, Lu J, Zhu G, Tamada K, Lennon VA, Celis E, Chen L. Tumor-associated B7-H1 promotes T-cell apoptosis: a potential mechanism of immune evasion. Nat Med. 2002; 8:793-800.

28. Brahmer JR, Tykodi SS, Chow LQ, Hwu WJ, Topalian SL, Hwu P, Drake CG, Camacho LH, Kauh J, Odunsi K, Pitot HC, Hamid O, Bhatia S, et al. Safety and activity of anti-PD-L1 antibody in patients with advanced cancer. N Engl J Med. 2012; 366:2455-2465.

29. Topalian SL, Hodi FS, Brahmer JR, Gettinger SN, Smith DC, McDermott DF, Powderly JD, Carvajal RD, Sosman JA, Atkins MB, Leming PD, Spigel DR, Antonia SJ, et al. Safety, activity, and immune correlates of anti-PD-1 antibody in cancer. N Engl J Med. 2012; 366:2443-2454.

30. Robert C, Ribas A, Wolchok JD, Hodi FS, Hamid O, Kefford R, Weber JS, Joshua AM, Hwu WJ, Gangadhar TC, Patnaik A, Dronca R, Zarour H, et al. Anti-programmed- death-receptor-1 treatment with pembrolizumab in ipilimumab-refractory advanced melanoma: a randomised dose-comparison cohort of a phase 1 trial. Lancet. 2014; 384:1109-1117.

31. Ansell SM, Lesokhin AM, Borrello I, Halwani A, Scott EC, Gutierrez M, Schuster SJ, Millenson MM, Cattry D, Freeman GJ, Rodig SJ, Chapuy B, Ligon AH, et al. PD-1 blockade with nivolumab in relapsed or refractory Hodgkin's lymphoma. N Engl J Med. 2015; 372:311-319.

32. Yang H, Bueso-Ramos C, DiNardo C, Estecio MR, Davanlou M, Geng QR, Fang Z, Nguyen M, Pierce S, Wei Y, Parmar S, Cortes J, Kantarjian H, Garcia-Manero G. Expression of PD-L1, PD-L2, PD-1 and CTLA4 in myelodysplastic syndromes is enhanced by treatment with hypomethylating agents. Leukemia. 2014; 28:1280-1288.

33. Arber DA, Orazi A, Hasserjian R, Thiele J, Borowitz MJ, Le Beau MM, Bloomfield CD, Cazzola M, Vardiman JW. The 2016 revision to the World Health Organization classification of myeloid neoplasms and acute leukemia. Blood. 2016; 127:2391-2405. 